\title{
Effects of Gas flaring on Surface water in Mkpanak Community of Akwa Ibom State, Nigeria
}

\author{
Ahuchaogu. I. Israel ${ }^{1}$, Ime Etim ${ }^{2}$ and Ofose. V. Etim ${ }^{3}$ \\ ${ }^{1,2 \& 3}$ Department of Agricultural and Food Engineering, \\ University of Uyo, Nigeria
}

\begin{abstract}
Gas Flaring is the process of burning off unwanted, flammable gases via combustion in an open atmosphere. It involves the emission of hydro carbons as well as greenhouse gasses. Works on impact of gas faring on soil in general and agricultural soil as well as on surface water have been investigated. This study attempts to bridge the dearth information on the impact of gas faring on surface water in Mkpanak Community with regards to its impacts on the agricultural and health sectors of the Community. Three surface water samples $\mathbf{S W}_{1}, \mathbf{S W}_{2}, \mathrm{SW}_{3}$ from the gas flaring area and three control water samples $\mathrm{CW}_{1}, \mathrm{CW}_{2}, \mathrm{CW}_{3}$ from a non-gas flaring area were analysed in the laboratory. The water samples were analysed for Physical, Chemical, Microbiological parameters and Heavy Metals content. Analysis was carried out using the standard methods of the American Society for Testing and Materials (ASTM) and American Public Health Association (APHA). The results showed that the mean concentrations of Turbidity, Electrical Conductivity, Total Dissolved Solids (TDS), Chemical Oxygen Demand (COD), Biochemical Oxygen Demand (BOD5), Potassium, Nitrates, Phosphates, Sulphates, Chromium, Cadmium, Iron, Zinc, E.coli and Total Plate Count were higher in the study area than the control area. Comparing the results with WHO and NSDWQ standards for drinking water quality, it was observed that most of the parameters were within the maximum permissible limits of WHO and NSDWQ except for Turbidity (11.72 NTU), Cadmium (0.62 mg/l), Nickel $(1.23 \mathrm{mg} / \mathrm{l})$, Iron $(1.37 \mathrm{mg} / \mathrm{l})$, Manganese $(1.42 \mathrm{mg} / \mathrm{l})$, Zinc $(0.48 \mathrm{mg} / \mathrm{l})$ and E.coli $(17.67 \mathrm{cfu} / 100 \mathrm{ml})$. Some of these parameters like Chromium and Phosphates were very close to the recommended limits and these could have negative health effects when ingested over a long period of time. The results of 10 trace elements (heavy metals) were also compared with the FAO irrigation standards. It was observed that Cadmium $(0.62 \mathrm{mg} / \mathrm{l})$, Manganese $(1.42 \mathrm{mg} / \mathrm{l})$ and Nickel $(1.23 \mathrm{mg} / \mathrm{l})$ were above the recommended limits and these could have negative effects on plants if used for irrigation. It was concluded that gas faring in the area has a significant negative effects on the agricultural activities and health standards of the study area.
\end{abstract}

Keywords: Gas faring, surface water, water sample, agriculture, health.

\section{INTRODUCTION}

Water is essential natural resources, a basic human need and very important national asset, therefore its use requires appropriate planning, development and management [31]. Considering the fact that water is very important in the sustenance of life, a satisfactory, safe, adequate and accessible supply must be made available to all [29]. Water pollution is the contamination of water bodies by the introduction of certain pollutants directly or indirectly by the uncoordinated activities of man. These pollutants not only make water unsafe for drinking, but also unsuitable for other domestic, industrial and agricultural purposes [14].

The exploitation and exploration of oil has been of great gain to Nigeria but the negative results emanating from such production processes have been very disastrous. One of such is gas flaring which locally and globally threatens the world ecosystem, global health, agriculture and water security through emission of toxins into the water, land and air [22]. Heat generated from gas flaring kills surrounding plant, suppresses the growth and flowering of some plants thereby reducing crop yield, induced soil degradation, destroys aquatic life and diminishes agricultural production [26]. The community used as a case study is facing the challenges caused by gas flaring on their air, water (surface and underground), crops and general ecosystem. The incidence of acid rain, Green House Gas Emissions (GHGE) have disrupted the economic lives of the people in Mkpanak Community of Ibeno Local Government of Akwa Ibom State, hence this research was carried out. The result is expected to create awareness on the impact of gas flaring on surface waters in the studied area and to assist Government, stakeholders, environmentalist, regulating agencies in making proper laws, rules and regulations to mitigate and eliminate the problem of gas flaring in the area as well as provide data bank for research purposes. Reference [3] defined gas flaring as the complex and unscientific process of burning natural gases which are related with crude oil when it is pumped out from the ground. Reference [30] describes gas flaring as the environmental pollution originating from human activities that involves the wasteful emission of greenhouse gases (GHGs) that causes global warming, disequilibrium of the earth's ecosystem, unpredictable weather changes and major natural disasters because of emission of benzene and other toxic substances that are harmful to humans, plants, animals and the entire physical environment. Reference [4] explained that incomplete combustion of these hydrocarbons (crude oil) can lead to the formation of carbon II oxide (CO) while the irregular crude components give rise to polycyclic aromatic hydrocarbons (PAH) and Volatile Organic Compounds (VOC). Gas flaring has a deterring effect on agriculture owing to the composition of 
gases as well as changes in temperature which happens during the flaring process. This contaminates the atmosphere with oxides of Nitrogen, Carbon and Sulphur $\left(\mathrm{NO}_{2}, \mathrm{CO}_{2}, \mathrm{CO}, \mathrm{SO}_{2}\right)$, particulate matters, hydrocarbon and ash, photo chemical oxidants and hydrogen Sulphide [19] and [13]. The resultant effects of these are increased acidity of the soil thereby reducing soil nutrient [11], increase in surrounding soil $\mathrm{pH}$ due intensity of heat [25], giving rise to crops stunted growth, scotched plants, polluted surface and underground water, delay in plant fruiting and maturation in addition to permanent wilting of plants [21]. These all concluded that the soil of the areas they studied lost their fertility and capacity for sustainable agriculture due to acidifications of soil by the various pollutants associated with gas flaring without examining the effects of flaring on surface water as [9] observed that gas flaring leads to severe degradation of the environment causing loss of livelihood and health related issues.

\section{MATERIALS AND METHODS}

\section{Description of Gas Flaring Areas}

Ibeno Local Government Area is one of the 31 Local Government Areas in Akwa Ibom State, Nigeria. The study area is located between Latitude $4^{0} 30^{\prime}-4^{0} 35^{\prime}$ North of the Equator and Longitude $7^{0} 50^{1}-8^{0} 20^{1} \mathrm{E}$ of the Greenwich Meridian. The area is located on the coastal plain sand of South Eastern Nigeria, and is within the mangrove and fresh water swamp forest belt. The area has rain throughout the year with the peak between May and September. The climatic condition in Ibeno is favorable all year round for fishing and farming. The people are basically of the Obolo/Andoni origin hence they speak a common language with people from Eastern Obolo called Obolo language. The main occupation of the people is fishing; however farming and petty trading is also very common.

The average temperature, wind speed and relative humidity of the Study area is about $83^{\circ} \mathrm{F}\left(28^{\circ} \mathrm{C}\right), 5 \mathrm{mph}(8 \mathrm{~km} / \mathrm{h})$ and $70 \%$ respectively. Ibeno Local Government Area has twenty-seven (27) Communities with a population figure of 75,380 people [16]. Mkpanak is one of the Communities in Ibeno Local Government Area where gas flaring occurs and flow station belonging to Exxon Mobil Producing Nigeria Limited is located. The flare station is located (Figure 1) very close to Qua Iboe Terminal (QIT) near Golf course in Mkpanak Community. The distance between the gas flared area and non-gas flared area all within Akwa Ibom State is about $153 \mathrm{Km}$. 


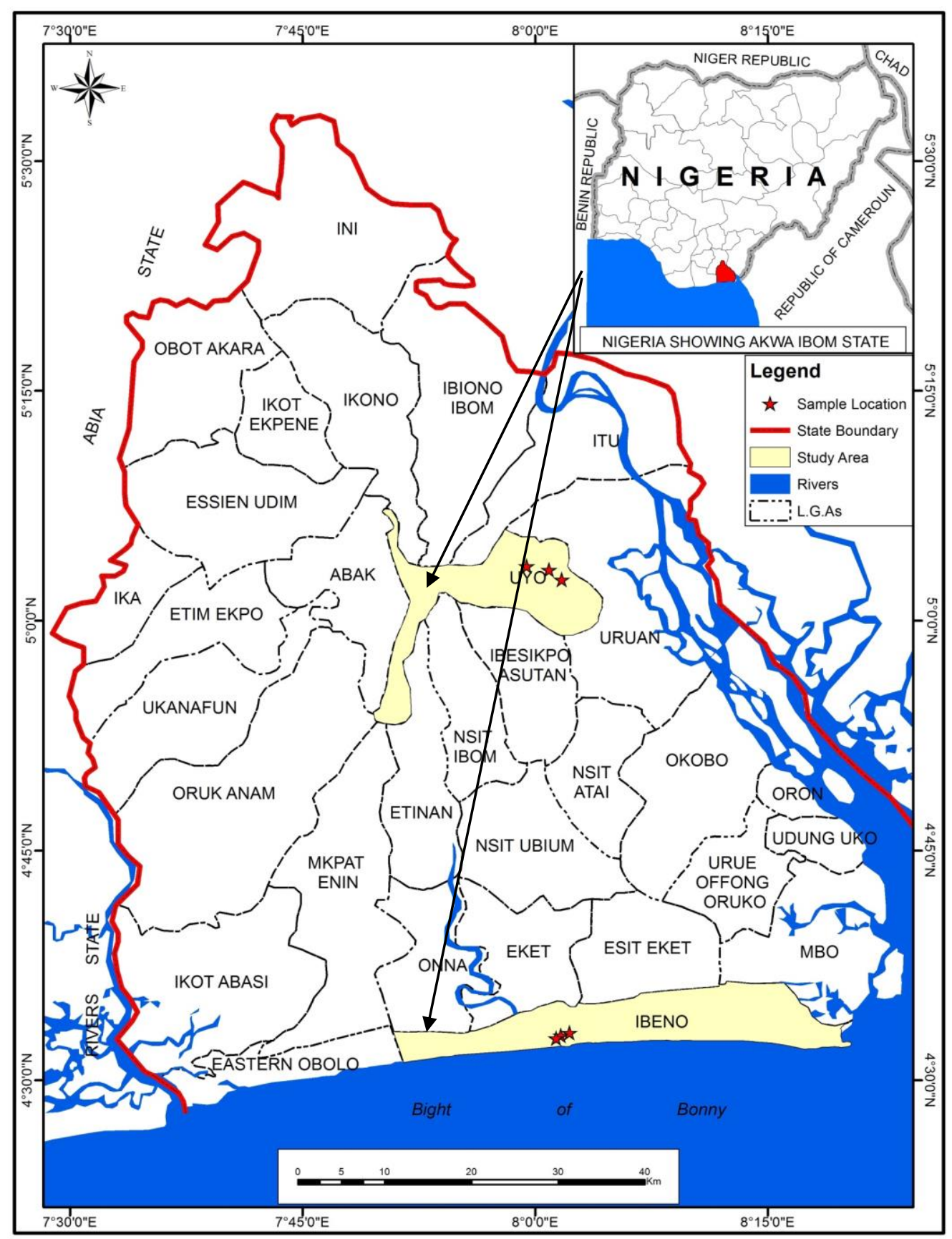

Figure 1: Akwa Ibom State showing Study Area and Control Area

\section{DESCRIPTION OF NON-GAS FLARING AREAS (CONTROL AREA)}

Uyo Local Government Area is one of the 31 Local Government Areas in Akwa Ibom State. The Control area lies between Latitude $5^{\circ} 1.763^{\prime \prime}-5^{\circ} 2.609^{\prime}$ north of the Equator and Longitude $7^{\circ} 57.506^{\prime \prime}-7^{\circ} 59.696^{\prime}$ east of the Greenwich Meridian. The population of Uyo according to the 2006 Nigerian Census which comprises Uyo and Itu was given as 427,873 while the urban area, including Uruan is 554,906 [16]. The people of Uyo Local Government Area are predominantly farmers and traders. Their area of trade is mostly on food items like palm oil, vegetables, fruits, cassava, yam etc. Uyo people are basically of the Ibibio origin and hence they speak the Ibibio Language (Figure 1). The average temperature, wind speed and relative humidity is about $78^{\circ} \mathrm{F}\left(26^{\circ} \mathrm{C}\right), 4 \mathrm{mph}$ $(6 \mathrm{~km} / \mathrm{h})$, and $82 \%$ respectively.

\section{SURFACE WATER SAMPLING}

Samples of surface water from three different locations in Mkpanak Community were collected with three sterilised polyethylene bottles and were labeled as $\mathrm{SW}_{1}, \mathrm{SW}_{2}$ and $\mathrm{SW}_{3}$ respectively. The control surface water samples were collected from three different locations in Uyo as well with 
three sterilised polyethylene bottles and were labeled as $\mathrm{CW}_{1}, \mathrm{CW}_{2}$, and $\mathrm{CW}_{3}$. Global positioning System (GPS, model Garmin GPSMAP 78s) was used for sampling position and easy identification. Samples were taken to the Ministry of Science and Technology laboratory for storage and preservation immediately after collection to avoid contamination and introduction of foreign materials before analysis were carried out. Table 1 shows the coordinates of surface water sampling points for the gas flaring and nongas flaring points.

Table 1: Coordinates of Surface Water Sampling Points

\section{Sampling Points}

$\mathrm{SW}_{1}$ : Mkpanak (Terminal)

$\mathrm{SW}_{2}$ : Iwuo-Ukpom (Big Town)

$\mathrm{SW}_{3}$ : Ibaka Waterside (Jetty Beach)

$\mathrm{CW}_{1}$ : Use Offot (Uniuyo Main Campus)

$\mathrm{CW}_{2}$ : NsukaraOffot (Ette-Ekpo borrow pit)

$\mathrm{CW}_{3}$ : EkpriNsukara (Ikot-Ituen borrow pit)

\section{Coordinates (Northing/Easting)}

$04^{0} 32.984^{\prime} \mathrm{N} / 007^{0} 59.632^{\prime} \mathrm{E}$
$04^{0} 32.818{ }^{\prime} \mathrm{N} / 007^{0} 59.344^{\prime} \mathrm{E}$
$05^{0} 02.378^{\prime} \mathrm{N} / 007^{0} 58.904^{\prime} \mathrm{E}$
$05^{0} 01.763^{\prime} \mathrm{N} / 007^{0} 59.696^{\prime} \mathrm{E}$
$05^{0} 02.609^{\prime} \mathrm{N} / 007^{0} 57.506^{\prime} \mathrm{E}$

\section{Laboratory Analysis of Collected Samples}

Analysis was carried out using the standard methods of the American Society for Testing and Materials, [2] and American Public Health Association, [1]. The laboratory analysis carried out on the collected samples (gas flaring point and non-gas flaring point) include the physical, chemical (including heavy metals analysis) and microbiological parameters. The physical parameters analysed were Temperature, Colour, Transparency, Turbidity, Odour. Chemical parameters checked were pH, Electrical Conductivity (EC), Total Dissolved Solid (TDS), Salinity as in chloride ion level $\left(\mathrm{Cl}^{-}\right), \mathrm{BOD}_{5}, \mathrm{COD}$, Dissolved Oxygen (OD), Oxides of Nitrogen, Sulphur,

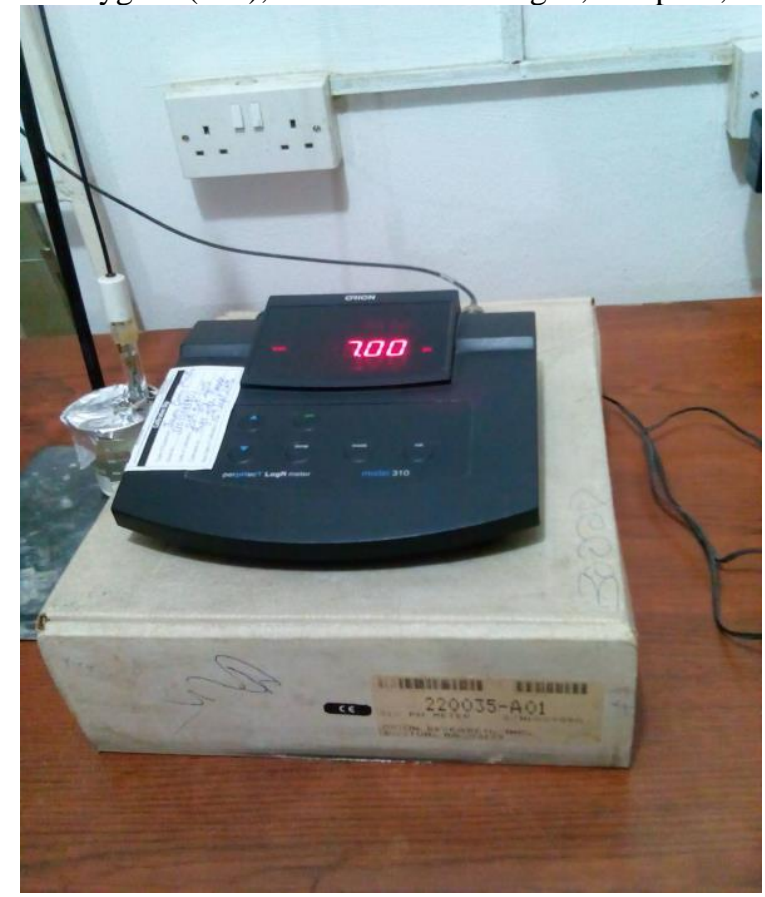

Plate 1: Thermo Orion pH meter (model 310)
Phosphorous, Potassium and Sodium ions adopting standard procedures. Digestion process was carried out using fume cupboard coupled with Atomic Absorption Spectrometer (AAS- model Unicam SOLAAR 969) appropriately to analysed the possibility of heavy metals presence. Microbiological analysis was carried out with the aid of a microbial incubator (Model 100.800) which was used to grow and maintain the microbiological cultures or cell cultures. The incubator maintained the optimal temperature, humidity of the samples and other conditions such as Carbon IV Oxide $\left(\mathrm{CO}_{2}\right)$ and the Oxygen content of the atmosphere inside.

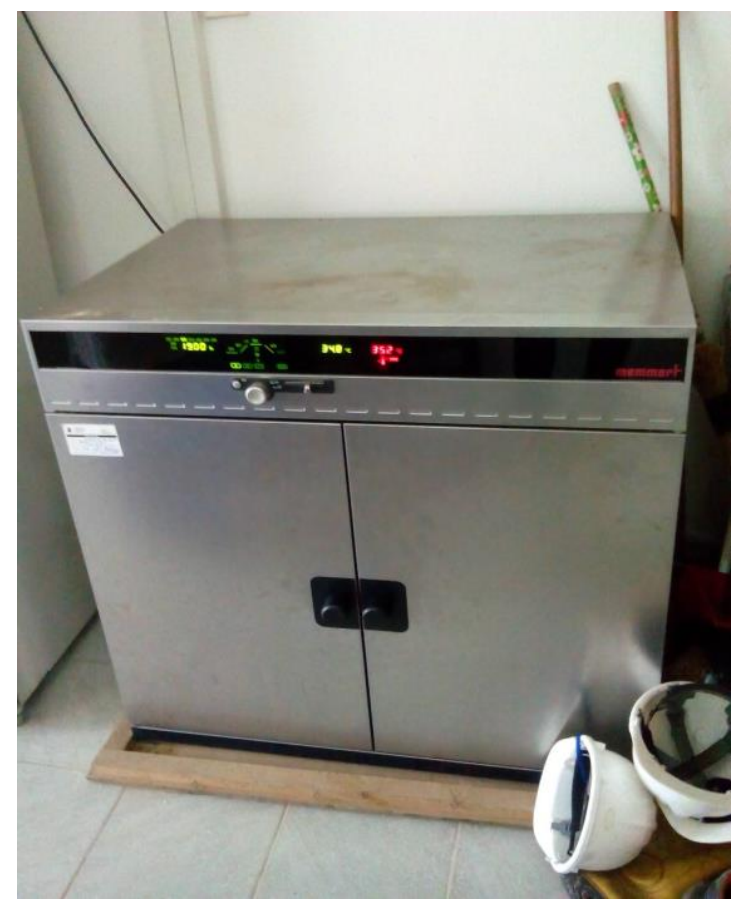

Plate 2: Microbial Incubator (Model 100.800) 


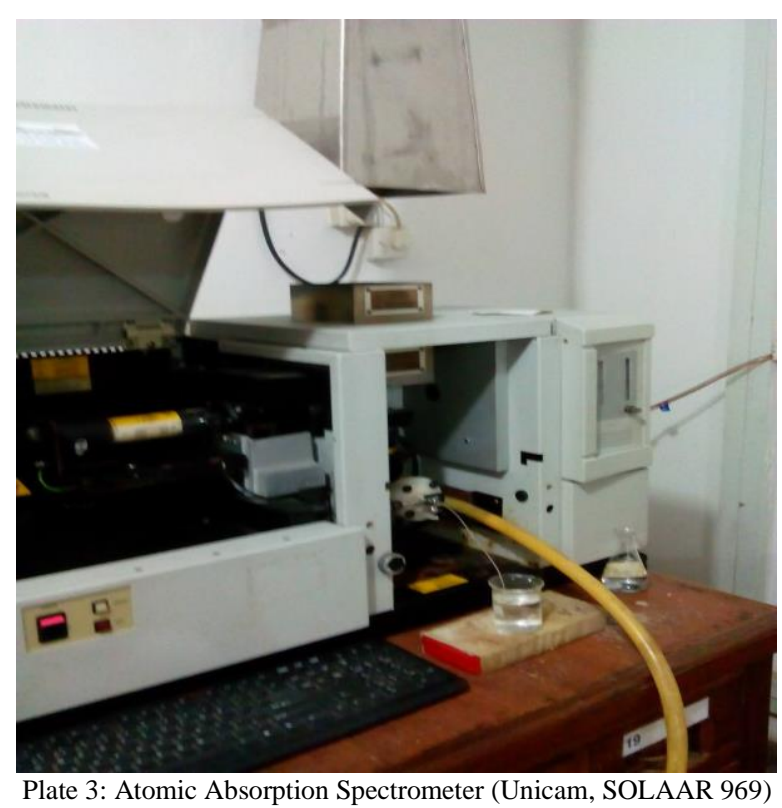

RESULTS AND DISCUSSION

Comparison of the average water sample in the study area with the average of the water sample from the control area, World Health Standard [28] and Nigerian Standard for
Drinking Water Quality [17] for purpose of identifying and validating if the results of samples analyzed fall within [28] and [17] standards, Table 2.

Table 2: comparison of analyzed results from gas faring and non-gas faring samples WHO (2008) and (NSDWQ, 2007)

\begin{tabular}{|c|c|c|c|c|c|}
\hline \multirow{4}{*}{$\mathbf{S} / \mathbf{N}$} & \multirow{4}{*}{ Tested Parameters } & \multirow{2}{*}{\multicolumn{3}{|c|}{ Mean values + }} & \multirow{4}{*}{$\begin{array}{l}\text { NSDWQ (2007) } \\
\text { Acceptable Range }\end{array}$} \\
\hline & & & Mean values \pm & & \\
\hline & & \multirow{2}{*}{$\begin{array}{l}\text { Standard } \\
\text { of } \text { Deviation } \\
\text { samples }\end{array}$} & \multirow{2}{*}{$\begin{array}{l}\text { Standard } \\
\text { Deviation of non- } \\
\text { gas flared samples }\end{array}$} & \multirow[t]{2}{*}{ Acceptable Range } & \\
\hline & & & & & \\
\hline A. & Physical Parameters & & & & \\
\hline 1. & Temperature $\left({ }^{\circ} \mathrm{C}\right)$ & $25.30 \pm 0.10$ & $25.50 \pm 0.10$ & $27-28$ & Ambient \\
\hline 2. & Odour & Odourless & Odourless & Unobjectionable & Unobjectionable \\
\hline 3. & Colour (H/N) & Inoffensive & Inoffensive & 5 & 15 \\
\hline 4. & Transparency & Clear & Clear & - & - \\
\hline 5. & Turbidity (NTU) & $11.72 \pm 0.84$ & $7.63 \pm 3.03$ & 5 & 5 \\
\hline B. & Chemical Parameters & & & & \\
\hline 6. & $\mathrm{pH}$ & $6.46 \pm 0.10$ & $6.46 \pm 0.05$ & $6.5-8.5$ & $6.5-8.5$ \\
\hline 7. & Electrical Conductivity $(\mu \mathrm{S} / \mathrm{cm})$ & $9.07 \pm 3.41$ & $6.75 \pm 0.75$ & 1000 & 1000 \\
\hline 8. & TDS (mg/l) & $4.17 \pm 1.61$ & $3.40 \pm 0.04$ & 500 & 500 \\
\hline 9. & $\mathrm{TSS}(\mathrm{mg} / \mathrm{l})$ & $0.14 \pm 0.02$ & $0.16 \pm 0.02$ & - & - \\
\hline 10. & Total Hardness & $20.17 \pm 4.47$ & $22.50 \pm 0.10$ & - & 150 \\
\hline 11. & Salinity as $\mathrm{Cl}^{-}$ & $4.48 \pm 0.23$ & $4.64 \pm 0.02$ & - & 250 \\
\hline 12. & $\mathrm{DO}(\mathrm{mg} / \mathrm{l})$ & $7.34 \pm 0.56$ & $7.80 \pm 0.06$ & - & - \\
\hline 13. & COD (mg/l) & $0.24 \pm 0.09$ & $0.18 \pm 0.00$ & - & - \\
\hline 14. & $\mathrm{NO}_{3}^{-}(\mathrm{mg} / \mathrm{l})$ & $1.03 \pm 0.45$ & $0.79 \pm 0.29$ & 50 & 50 \\
\hline 15. & $\mathrm{SO}_{4}{ }^{2-}(\mathrm{mg} / \mathrm{l})$ & $2.02 \pm 0.03$ & $0.99 \pm 0.21$ & - & 100 \\
\hline 16. & $\mathrm{PO}_{4}{ }^{3-}(\mathrm{mg} / \mathrm{l})$ & $2.93 \pm 0.26$ & $1.71 \pm 0.64$ & 3.50 & - \\
\hline 17. & $\mathrm{BOD}_{5}(\mathrm{mg} / \mathrm{l})$ & $0.10 \pm 0.02$ & $0.09 \pm 0.00$ & - & - \\
\hline 18. & Potassium (K) & $5.36 \pm 0.98$ & $4.73 \pm 1.07$ & - & - \\
\hline 19. & Sodium $(\mathrm{Na})$ & $9.57 \pm 0.61$ & $10.44 \pm 1.48$ & - & 200 \\
\hline C. & Heavy Metals (mg/l) & & & & \\
\hline 20. & Lead $(\mathrm{Pb})$ & $0.00 \pm 0.00$ & $0.00 \pm 0.00$ & 0.01 & 0.01 \\
\hline 21. & Copper $(\mathrm{Cu})$ & $0.00 \pm 0.00$ & $0.00 \pm 0.00$ & 2.00 & 1.00 \\
\hline 22. & Zinc $(\mathrm{Zn})$ & $0.48 \pm 0.11$ & $0.35 \pm 0.04$ & 3.00 & 3.00 \\
\hline 23. & Cadmium $(\mathrm{Cd})$ & $0.62 \pm 0.36$ & $0.48 \pm 0.04$ & 0.003 & 0.003 \\
\hline 24. & Arsenic (As) & $0.00 \pm 0.00$ & $0.00 \pm 0.00$ & 0.010 & 0.010 \\
\hline 25. & Vanadium (V) & $0.00 \pm 0.00$ & $0.00 \pm 0.00$ & - & - \\
\hline 26. & Nickel (Ni) & $1.23 \pm 0.19$ & $1.30 \pm 0.29$ & 0.070 & 0.020 \\
\hline 27. & Iron $(\mathrm{Fe})$ & $1.37 \pm 0.13$ & $1.25 \pm 0.28$ & 0.300 & 0.300 \\
\hline 28. & Chromium (Cr) & $0.04 \pm 0.01$ & $0.03 \pm 0.01$ & 0.050 & 0.050 \\
\hline 29. & Manganese (Mn) & $1.42 \pm 0.46$ & $1.43 \pm 0.48$ & 0.400 & 0.200 \\
\hline \multirow[t]{4}{*}{ D. } & Microbiological parameters & & & & \\
\hline & E.Col $(\mathrm{cfu} / 100 \mathrm{ml})$ & $17.67 \pm 2.52$ & $17.00 \pm 7.00$ & - & 0 \\
\hline & $\mathrm{TPC}(\mathrm{cfu} / 100 \mathrm{ml})$ & $17.33 \pm 5.03$ & $12.00 \pm 4.00$ & - & - \\
\hline & YeastMould (cfu)(100ml) & $3.50 \pm 2.12$ & $1.00 \pm 1.41$ & - & - \\
\hline
\end{tabular}




\section{PHYSICAL PARAMETERS}

Measurement of temperature was carried out to determine the degree of hotness or coldness of the surface water samples. The mean temperature of the water samples collected from the study area was $25.30^{\circ} \mathrm{C}$ which was slightly lower than that of the control area and was not within the acceptable range by the World Health Organization Standard [28], Table 2. The normal advisable level for temperature as stipulated by $\mathrm{WHO}$ is within the range of $27^{\circ} \mathrm{C}-28^{\circ} \mathrm{C}$ although it was close to the ambient temperature recommended by the [17]. These could be due to the weather condition when the samples were taken from both the study and control area.

Turbidity has to do with the measure of the cloudiness or clarity of water caused by large number of individual particles that are generally invisible to the naked eye. Turbidity is affected by the Total Dissolved Solids (TDS) in the water. The higher the TDS of the water samples, the higher the turbidity of the water samples and may be due to increased pollution of the surface water from the activities of oil and gas companies operating in the area [24]. The Turbidity values for the surface water in the gas flaring area ranged from 10.95-12.62 NTU compared to 4.60$10.65 \mathrm{NTU}$ in the non-gas flaring area. The values are above the limits recommended by [28] and [17]. This makes the water samples from both the study area and control area unsuitable for drinking because the high turbidity values indicates that the surface water has been polluted by the activities of man. In drinking water, the higher the turbidity level, the higher the risk that people may develop gastrointestinal diseases [15].

The water samples from the Gas flared Community and the Control Community were Clear, Inoffensive and Odourless. This observation showed that the gas flares did not affect the Transparency, Colour and Odour of the surface waters in Mkpanak Community, Table 2. These results did not agree with those of [18]. These differences could be due to the fact that the water samples were collected from both the study area and the control area during a period of high rainfall leading to the reduction of the effects of these flared gas on the water samples.

\section{CHEMICAL PARAMETERS}

According to reference [8], the $\mathrm{pH}$ is a very important factor for determining the quality of water because it controls the solubility and availability of mineral nutrients and heavy metals. The mean $\mathrm{pH}$ value for the surface water in both the study area and control area which was 6.46 was close to the acceptable range of $6.5-8.5$ recommended by [28] and [17]. Although it lies slightly on the acidic side, the surface water may therefore be regarded as being neutral [8].

Electrical conductivity is a measure of the capacity of water to conduct electrical current. It is connected to the presence of ionic species in solution [5]. This study showed that the surface water from the gas flared area had electrical conductivity ranging from 7.0-13.0 $\mu \mathrm{S} / \mathrm{cm}$ compared to $6.0-$ $7.5 \mu \mathrm{S} / \mathrm{cm}$ for the non-gas flaring area although they were within the recommended limits of [28] and [17]. The observed high conductivity of the surface waters in the study area indicated that the water was in contact with inorganic substances originating from the emissions of the flared gasses [7].

Total Hardness is the total concentration of multivalent metallic cations in solution. Dissolved Calcium and Magnesium ions are the major sources of hardness in water whereas minor contribution is made by the ions of Aluminum, Barium, Manganese, Iron, Zinc, etc. The mean value of hardness gotten from the control area was $22.50 \mathrm{mg} / \mathrm{l}$ compared with $20.17 \mathrm{mg} / \mathrm{l}$ from the study area. This was well below the threshold limit of $150 \mathrm{mg} / \mathrm{l}$ as recommended by [17]. Thus surface water from non-gas flaring areas is harder than surface waters from gas flaring areas because of the higher mean value for Total hardness in the study area. The increased hardness can reduce lather formation of soaps and increase the scale formation on hot water [18].

Generally, the concentration of TDS is proportional to the degree of pollution. The TDS in the gas flaring area ranged from 3.0-6.0 mg/l while that from the non-gas flaring area ranged from $3.0-3.8 \mathrm{mg} / \mathrm{l}$ and were far below the maximum limits recommended by [28] and [17].The increase in TDS in the surface water of Mkpanak Community compared with the non-gas flared Community in this study could be due to increased pollution to the surface water from the activities of oil and gas companies operating there. Furthermore, high amount of TDS have been observed due to industrial pollution [24]. The values of Total suspended Solids in the gas flaring areas ranged from $0.12-0.16 \mathrm{mg} / \mathrm{l}$. This was very low and almost the same with that of the non-gas flaring area which ranged from $0.14-0.18 \mathrm{mg} / \mathrm{l}$. These could be because the water samples from both the Gas flaring area and non-gas flaring area contained an appreciable amount of dissolved substances derived from surface runoff or overland flow. Biochemical Oxygen Demand $\left(\mathrm{BOD}_{5}\right)$ is the amount of dissolved oxygen required by aerobic biological organisms in a body of water to break down organic material present in a given water sample at a certain temperature over a specific period of time. It is widely used as an indication of the organic quality of water [6]. The amount of dissolved oxygen required to break down organic materials in the study area ranged from $0.08-0.12 \mathrm{mg} / \mathrm{l}$ compared to an average $0.09 \mathrm{mg} / \mathrm{l}$ in the control area.

According to reference [24] Dissolved Oxygen (DO) is very important for many chemical and biological processes taking place in water. A stream must have a minimum of about $2 \mathrm{mg} / \mathrm{l}$ of DO to maintain higher life forms. The average concentration of DO which is a measure of how much the water samples is saturated with oxygen for the study area was $7.34 \mathrm{mg} / \mathrm{L}$ compared with $7.80 \mathrm{mg} / \mathrm{l}$ in the control environment. The observed lower values of DO in study area compared with the control area may be due to high decomposition of organic matter, which can also indicate high pollution load in the water following many years of continuous gas flaring in the environment. The deficiency of Oxygen in the water can be a shelter for 
bacteria and other pathogens, which are injurious and dangerous to human health [23].

The Chemical Oxygen Demand (COD) is commonly used to indirectly measure the quantity of organic compounds in water [6]. The surface water sources from the gas flared area had COD range of $0.16-0.34 \mathrm{mg} / \mathrm{l}$ compared with the constant $0.18 \mathrm{mg} / \mathrm{l}$ from the non-gas flared area. The increased COD in the study area is an indication of pollution due to gas flaring. The flares associated with gas flaring gives rise to atmospheric contaminants which include the oxides of Nitrogen, Carbon and Sulphur $\left(\mathrm{NO}_{2}\right.$, $\mathrm{CO}_{2}, \mathrm{CO}, \mathrm{SO}_{2}$ ), [19] and [13]. It was observed that the mean concentrations of phosphates $(2.93 \mathrm{mg} / \mathrm{l})$, sulphates $(2.02 \mathrm{mg} / \mathrm{l})$ and nitrates $(1.03 \mathrm{mg} / \mathrm{l})$ which are the main constituents of the flared gasses was higher in the surface waters in the gas flaring area than the mean concentrations of phosphates $(1.71 \mathrm{mg} / \mathrm{l})$, sulphates $(0.99 \mathrm{mg} / \mathrm{l})$ and nitrates $(0.79 \mathrm{mg} / \mathrm{l})$ in the control area. These variations is an indication that gas flaring increases the concentrations of Nitrates, Sulphates and Phosphates in the surface waters of Mkpanak Community.

Concentrations of Nitrates in rain water and surface water have been observed in industrial areas [27]. Excessive levels of these Nitrates in drinking water can cause serious illness such as the Blue Baby Disease (Methemoglobinemia) which is due to the conversion of nitrates to nitrite by the body can interfere with the oxygen carrying capacity of a child's blood leading to shortness of breath and blueness of skin. Excessive concentrations of Nitrates in drinking waters ingested over a long period of time can cause diuresis and hemorrhaging of the spleen [28]. The levels of Sulphates in rain water and surface water correlates with emissions of Sulphur dioxide from anthropogenic sources [12]. According to reference [10], dehydration and laxatives effects are the common side effects following the ingestion of large amounts of Sulphates. Concentrations of phosphates in very large amounts in drinking water can lead to respiratory problems.

\section{HEAVY METALS}

The following heavy metals Lead, Copper, Arsenic and Vanadium which can cause cancer were not detected in the surface water in both the gas flaring environment and nongas flaring environment as shown in Table 1 and Table 2. This implies that the water is free from heavy toxic metals that have been implicated elsewhere [20]. The mean concentration of Zinc in the study area was $0.48 \mathrm{mg} / \mathrm{l}$ compared to $0.35 \mathrm{mg} / \mathrm{l}$ in the control area. This was within the $3.00 \mathrm{mg} / \mathrm{l}$ limits recommended by [28] and [17].

The mean concentrations of Manganese in the surface water of the control area $(1.43 \mathrm{mg} / \mathrm{l})$ was slightly higher than that of the study area $(1.42 \mathrm{mg} / \mathrm{l})$ and were both outside the maximum permitted limits by [28] and [17]. The higher concentrations of Manganese can cause undesirable and objectionable taste of the surface waters when utilized for drinking purposes [29].
The two largest sources of Chromium emission in the atmosphere are from the chemical manufacturing industries and the combustion of natural gas, oil and coal. The mean concentrations of Chromium in the surface water of the study area $(0.04 \mathrm{mg} / \mathrm{l})$ was slightly higher than that of the control area $(0.03 \mathrm{mg} / \mathrm{l})$ and were both within the recommended limits by [28] and [17]. Drinking water containing large concentrations of Chromium over a short period of time can lead to skin irritation or ulceration while ingestion over a long period of time can lead to liver or kidney damage [29]. The mean concentration of Potassium in the surface water of the area with gas flaring activities $(5.36 \mathrm{mg} / \mathrm{l})$ was higher when compared with the area without gas flaring activities $(4.73 \mathrm{mg} / \mathrm{l})$. The average amount of Sodium in the study area was below the average amounts found in the control area and both were below the threshold limits of the [28] limits. This means that gas flaring activities did not affect the concentration of sodium in the surface waters of Mkpanak Community.

\section{MICROBIOLOGICAL PARAMETERS}

Escherichia coli are utilized as a microbial measure of drinking water quality, largely because they are easy to detect and enumerate in water. The Coliforms bacterial count values in the surface waters in Mkpanak Community are extremely high ranging from $15-20 \mathrm{cfu} / \mathrm{ml}$ as against $10 \mathrm{cfu} / 100 \mathrm{ml}$ recommended by WHO for potable water [28]. Therefore, the surface water in Mkpanak Community is not fit for drinking on account of the Coliforms bacterial count as this could cause bloody diarrhea or abdominal cramps. Faecal contamination from human, wild animals and runoffs from domestic homes and agricultural farmlands could have been the source of the Coliforms bacteria in the surface waters [20]. The total plate count is a measure of how many aerobic microorganisms will grow in 72 hours on an agar plate that was formed for microbiological testing at a controlled temperature. The total plate count averaged in the surface waters of the study area $17.33 \mathrm{cfu} / 100 \mathrm{ml}$ was higher than the average Total plate count in the control area which was about $12.00 \mathrm{cfu} / 100 \mathrm{ml}$. The higher total plate count in the study area indicated the presence of organic substances in the surface waters which can be linked to the gas flaring activities in the area and faecal discharges into the surface water directly or indirectly [24].

\section{CONCLUSION}

Gas flaring in Mkpanak Community has a serious effect on surface waters since the suspended particulate matter and gases emitted during gas flaring have increased the concentrations of some of these Physical, Chemical and Microbiological parameters as well as Heavy Metals in the water samples of the study area when compared with samples from the control area as well as recommended limits of World Health Organization [28] and Nigerian standard for Drinking Water Quality [17]. 


\section{REFERENCES}

[1] APHA , American Public HealthAssociation (1998). Standard methods for examination of water andwastewater. $20^{\text {th }}$ Edition, Washington, D.C.

[2] ASTM , American Society for Testing and Materials (1999). Standard methods for examination of water and wastewater. $21 \mathrm{st}$ Edition, Washington, D.C.

[3] Ajugwo, A. O., (2013). Negative Effects of Gas Flaring: The Nigerian Experience. Journal of Environment Pollution and Human Health, Vol. 1, No. 1, 6-8. pp.6-7.

[4] Bott, R. D. (2007). Canadian Centre for Energy Information: Flaring: Questions and answers. Calgary, Alta: Canadian Centre for Energy Information. ISBN 1-894348-18-4 pp. 12.

[5] Boukari, M. (1998). Updating of hydrogeological knowledge about coastal sedimentary basin of Benin. Cotonou, 134.

[6] Clair, N. Sawyer, Perry L. McCarty, Gene F., Parkin (2003) Chemistry for Environmental Engineering and Science (5 ${ }^{\text {th }}$ ed.), New York: McGraw-Hill.

[7] Etu-Efeotor, J.O.(1998), Hydro chemical analysis of surface andground waters of Gwagwalada area of Central Nigeria,Global J. Pure Appl. Sci., 4(2), 153-162.

[8] Fakayode, S. O. (2005). Impact assessment of industrial effluent on water quality of the receiving Alaro River in Ibadan, Nigeria. Ajeam-Ragee, 10: 1-13.

[9] Farina, M. F. (2011). "Flare Gas Reduction: Recent Global Trends and Policy Considerations," General Electric Company.

[10] Fingl, E. W. (1980). Laxatives and Cathartics. In: Gilman Act et al., eds. Pharmacological basis of therapeutics New York. Macmillian Publishing.

[11] Imevbore, A. A. and Adeyemi, S. A, (1998). Environmental monitoring in relation to pollution andcontrol of oil pollution.Seminar on the petroleum industry and the Nigerian environment. 6. 135-142.

[12] Kelller, W. and Pitblade, J. R. (1986) water quality changes in Sudbury area lakes: a comparison of synoptic surveys in 19741976 and in 1981 -1983. Water, Air and Soil Pollution 29:285

[13] Kindzierski, W.D, (2000) "Importance of human environmental exposure to hazardous air pollutants from gas flares," Environmental Reviews, 8, 41-62.

[14] Kumar, M. and Padhy P. K. (2013). Climate change, water resources and food production some highlights. From India's stand point, Int. Research Journal of Environmental Science, 2 (1), $79-87$

[15] Mann, A. G., Tam, C. C., Higgins C.D. and Lodrigues, L. C. (2007). The association between drinking water turbidity and gastrointestinal illness: a systematic review. BMC Public Health. 7(256): $1-7$

[16] NPC (2006). Population and Housing Census of the Federal Republic of Nigeria: National Population Commission, S2006.

[17] NSDWQ (2007). Nigerian Standards for Drinking Water Quality, Standards Organization of Nigeria, Lagos Nigeria.

[18] Nwankwo C.N. and Ogagarue D.O. (2011). Effects of gas flaring on surface and ground waters in Delta State Nigeria, J. Geol. Mining Res., 3(5), 131-136.
[19] Obioh, I. B (1999)."Environmental Impact Assessment of Emissions from Major Facilities at QIT,"Atmospheric Emissions and Dispersion Modeling, Faithlink Consults Nigeria Ltd, PortHarcourt.

[20] Orjiekwe, C. L, Oshin D, Orjiekwe I. U. (2006). Water quality index assessment ofEvebonede and Ovia Rivers in Ovia NorthEast Local Government Area of Edo State, Nigeria. Int. J. Chem. 16(4):223-228

[21] Orimoogunje, O. I, Ayanlade, A, Akinkuolie, T. A. and Odiong, A. U. (2010). Perception on the Effect of Gas Flaring on the Environment. Research Journal of Environmental and Earth Science. 2(4). $188-193$.

[22] Ogbe, M. G. (1999). The Impact of Oil Exploration and Exploitation on the Niger Delta. A paper presented at the annual field trip of Geography and Regional Planning Students at Oleh, River State, Nigeria.

[23] Radha K.R., Dharmaraji K. and Ranjitha K. B. D. (2007). A comparative study on the physicochemical and bacterial analysis of drinking borehole and sewage in three different places of Sivakasi, J.Environ.Biol., 28(1), 105-108

[24] Shivayogimath C.B., Kalburgi P.B., Deshannavar U.B. and Virupakshaiah D.B.M. (2012), Water quality evaluation of riverGhataprabha, India, Int. Res.J.Environ. Sci., 1(1), 12-18.

[25] Ubani, E. C. and Onyejekwe, I. M, (2013)."Environmental impact analysis of gas flaring in the Niger delta region of Nigeria,' American J. of Scientific and Industrial Research. 4(2). 246 - 252.

[26] U.N.D.P. (2006). Niger Delta Human Development Report. Abuja, Nigeria. pp 185-187.

[27] Van Duijvenboden, W. R. and Matthijisen A. J. (1989). Integrated Criteria Document Nitrate. Bilthoven National Institute for Public Health and the Environment.

[28] WHO (2008). World Health Organization International drinking water standard, 3rd Edition Geneva.

[29] WHO (2011). World Health Organisation International Drinking Water Standard, $4^{\text {th }}$ edition, Geneva.

[30] World Bank, (1995).Defining and Environmental Strategy for the Niger Delta. West Central Africa Department, World Bank, Washington DC, Pp 150

[31] Yadav, J. Pathak, R. K and Khan, E. (2013) . Analysis of water quality using physio-chemical parameters. Satak Reservoir in Khargone District, MP, India. Int. Research Journal of Environmental Science 2 (1), 9 - 11 